\title{
FLEXIBLE EMPLOYMENT FORMS IN DIFFERENT COMPANIES LOCATED IN BUDAPEST
}

UDC: 331.108.34(639.151)

Original Scientific Paper

\author{
Ildiko CSAPÓ ${ }^{1}$, József POÓR ${ }^{1}$, Tímea JUHÁSZ ${ }^{2}$, Andrea VISZTENVELT ${ }^{1}$ \\ ${ }^{1}$ Szent István University, H-2100 Gödöllő, Páter Károly u. 1., Hungary \\ E-mail: ildiko.csapo10@gmail.com \\ ${ }^{2}$ Hungary
}

Paper received: 22.04.2017.; Paper accepted: 24.05.2017.

\begin{abstract}
Today, atypical employment, such as flexible forms of employment, has gained more important substantiality within work science researches. As a result of the economic crisis, the flexible employment form has appeared as an alternative solution, as it has cost reducing effects. The authors examined how the different companies -operating in the Hungarian capital- react to the economic crisis. Do they prefer the flexible employment forms as a possible and effective way of employment? In 2013 and 2015, the researchers also carried out a survey that tested the results of the current study and some results of the quantitative survey of the organizations were presented in Budapest. Based on the analysis in 2015, the organizations were more optimistic, and this is one manifestation of the willingness to expand employment as showed. The authors' aim with this study is to supply relevant answers regarding the new prospective methods of flexible employment.
\end{abstract}

Keywords: Atypical work, Flexible employment form, Economic crises, Alternative solution.

\section{INTRODUCTION}

The ever-changing economy, the technological development and the economy crisis in 2008 paved the way for atypical employment. The combined force of two major factors initiated development: knowledge economy and information technology. Companies realized that rapid provision of workforce both in face of time and geographical extension is a must for their survival. Atypical employment means the management of a multiplicity of employment forms and work orders. This is an employment form required by the dynamics of economy. Mostly the companies which gave up traditional ways of employment and evoked new, more flexible ones remained competitive. Atypical employment is a consequence of the need and also the means of the companies' ability to react to economic challenges and to achieve remarkable cost reductions. There are different primal forms of atypical employment depending on time and location. These differences can be explained by specific labour market traditions, established work structures and institutional measures affecting labour markets.
The forms of atypical employment are determined by the traditional employment rules and employment systems of the given countries. There are fundamental differences among Anglo-Saxon countries, the Central-East countries and Japan. These differences are influenced by tradition, economic circumstances, the state of development in the given country and the differences in their history and institutions. (Ogura, 2005)

What do we mean by atypical employment? Literature refers to these as employment methods differing from traditional ones and referred to as alternative ways of employment or provisional employment. The common platform of different definitions is that they all mention unorthodox ways of employment. (Szabó \& Négyesi, 2004)

Modern Human Resources Management could be found in traces only during the socialist regime in Central-Eastern European countries. In this region, 'scientific people management' prevailed. Preceding the transition of the political environment, HR activities were controlled by the 
state in these countries, (Lipták, 2011). This meant that personnel issues were closely supervised by the state and the Communist Party. Besides, there were significant alterations among countries regarding HR management. Tung and Harlovic (1996) spotlighted that police had lesser influence in Poland in comparison to Czechoslovakia. In Hungary, by the 80 's, a new view became dominant: economic reforms, organisational environment and HR were to be reformed in parallel. Before this movement personnel management was supervised centrally.

Political transition challenged HR departments by the mass dismissal of workers. Central-Eastern European dismissal practices were remarkably more human compared to those in Western Europe. Lewis (2004), in his book on the role of Western European countries, stated that multinational companies had a great impact on the labour market of socialist countries.

Multinational companies took advantage of their edge of resources against the relatively weak local institutions that were only in a hatching state. (Poór, Farkas, \& Engle, 2012)
'Atypical employment' is a term that appeared and spread in Europe in the 80's. Originally 'atypical job' was used. The International Labour Organisation (ILO) held a series of seminars with the aim of mapping of atypical employment forms and the social background of labourers employed in it. (Laky, 2001)

An advantage of human capital specific employment is that training low educated labour to a given work process, resulted in only small cost for companies. Furthermore, practicing the process and working in teams increased efficiency significantly. Although, human capital specific employment caused rigidity, intra firm HR policies were developed. In order to avoid cost increases, employers tended to employ workers long term. This was beneficial for both parties.

From the 80's onwards, the dominance of information technology supplanted traditional industrial technologies causing goods market turn upside down, and sharpening global competition see Figure 1. The application of information technology altered employment policies and a new employment form appeared - see Figure 2.

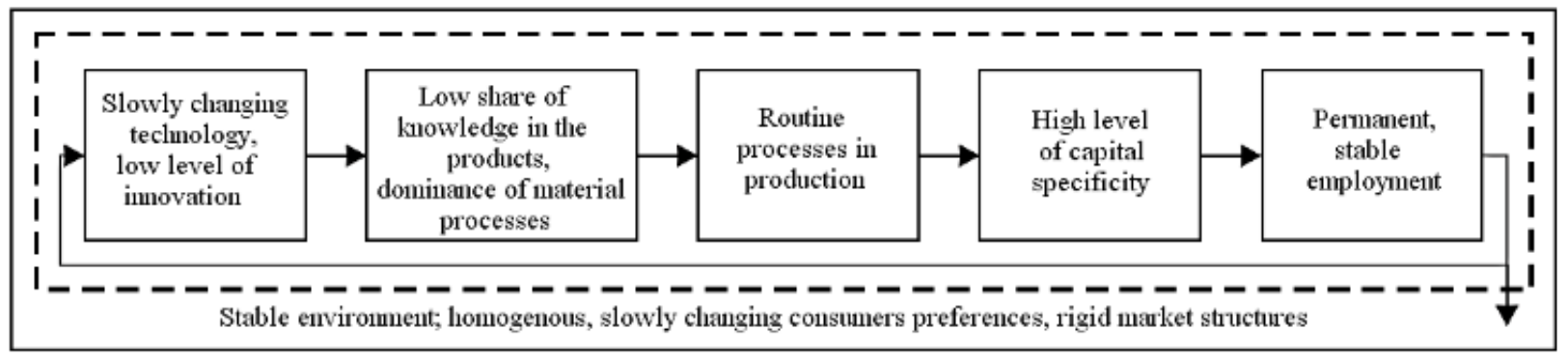

Figure 1: Employment model of the industrial age (Szabó \& Négyesi, 2004)

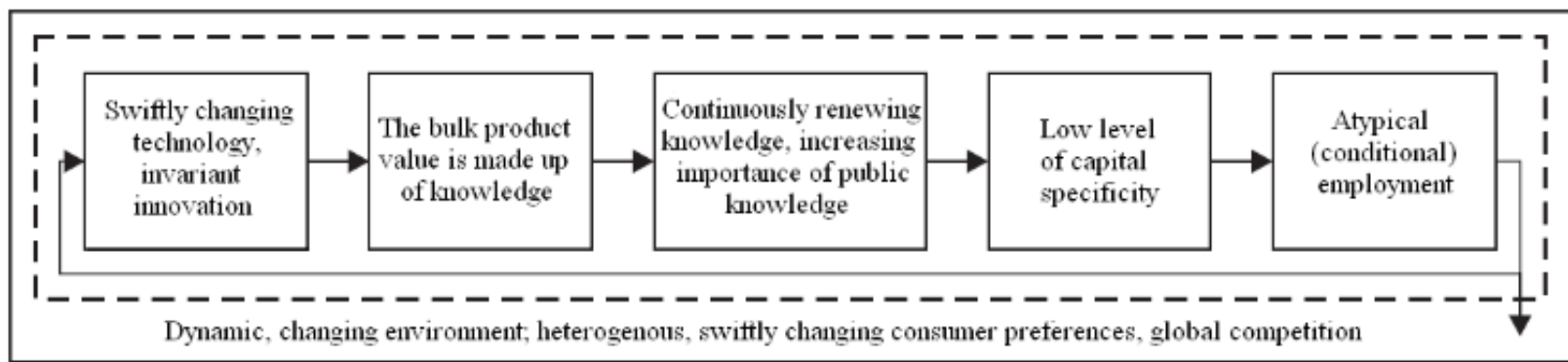

Figure 2: Employment model of the post-industrial society (Szabó \& Négyesi, 2004)

The category of "atypical" continuously broadened, though in the initial period only part time, individual and fixed-term employment forms were included in this category in the European Union (Broughton, Biletta, \& Kullander, 2010). Hungarian HR professionals also highlight only a few forms of atypical employment. These are part time employment, flexitime, job sharing and teleworking. (Bokor, Szőts-Kováts, Csillag, Bécsi, \& Szilas, 2007). Technical knowledge, technological development and the decline in the importance of agriculture generated unemployment. The ever 
increasing labour cost forced employers to search for solutions to employing workforce only as long as it is absolutely necessary (Hárs, 2013).

The EU legislation sets a so called 'minimal requirement", which is mandatory for all member states. The EU uses directives - in this case Article 153 - which are bases for these requirements. Within typical employment, there are inflexible, flexible and innovative forms of employment. Inflexible form is typical of indefinite duration employment with 40 hour/week work-time, from Monday till Friday, 8 hours a day or 8 hours 30 minutes' workdays from Monday till Thursday and 6 hours on Fridays. Only the immediate supervisor has the right of disposal over the work-time of his/her subordinates. Employees must perform their work at the premises of the employer and they must use the employer's equipment.

One of the aspects divides atypical employment into two groups: the one that is created by employers for flexibility, and the other one is introduced by governments in order to emancipate disadvantaged groups of workforces on the labour market, (Elbaum, 1988). Another possible way of classification is by special ways of employment: unorthodox distribution and number of working hours - part time, odd job - or special legal status and special way of working - home office, workforce rent, (Stavrou, 2005).

Hereafter are the definitions of the different ways of employment:

- Part time job: working days are shorter than 8 hours, part time workers enjoy the same rights as full timers do, (Laky, 2001).

- Tele work: work if performed in a location away from the employer's premises. Results of the work are sent to the employer by the means of IT and communication (Jacksona \& van der Wielen, 1998).

- Outworking: Laky (2001) refers to 'outworking' as a legal form of employment outside labour relationship. Confusion between the interpretation of outworking and that of self-employment is common.

- Self-employment: this is a tricky concept to give definition for, since there is not a commonly accepted one. In case of selfemployment, reimbursement is largely dependent on the results of the task.

- Fix-term labour contract has become internationally wide spread. A fixed-term employee is someone who is employed under a contract which contains a specific start and end date, or who is employed to carry out a specific task or project, or the continuity of whose contract is contingent on a particular event such as the availability of continued funding from an external source.

- Outsourcing: the term of outsourcing is derived from the Anglo-Saxon language area. These terms were used "Outside Resource Using" referred to the available resources outside the company.

- Temporary employment: according to Laky (2001) spotlights seasonal work within the category of temporary employment referring to its seasonal pattern. The duration of seasonal work may depend on natural circumstances.

\section{METHODOLOGY}

The research took place in 2013 and 2015. The first research was made as mutual project with the participation of Szent István University (Gödöllö, Hungary) and Selye János University (Komarno, Slovakia), (Strážovská, Strážovská, Szabó, Szabó, \& Vinogradov, 2014). The second survey was conducted by the Chamber of Békés County, the Chamber of Budapest, and the management and human resource research centre of Szent István University. In both cases the aim was to identify tools, methods used by the different firms at the time of the crisis and to describe the best practices regarding business- models and employment.

The researches focused on the atypical employment tools as valid answers within the structure to reduce the negative effects of the crisis.

The sample collecting method was the referral (snowball) sampling. This is a non-probability sampling technique where existing study subjects recruit future subjects from among their acquaintances. Thus, the sample group is said to grow like a rolling snowball. As the sample builds up, enough data are gathered to be useful for research, (Schleicher, 2007). The research in 2015 focused on firms operating in the Hungarian capital (Budapest), collecting 83 companies, and the previous research had also contained 87 organisations from the capital, so the researchers could compare the differences between the samples. Regarding the analysing method, experts used one, and multivariable processes, so they 
have made frequency, average and non-parametric examinations.

\section{RESULTS}

As we have mentioned before there were 87 examined firms in 2013, and 83 in 2015. The firms we have focused on were, in percentage $49.4 \%$ Hungarian- owned in 2015, 41\% were foreign companies, $6 \%$ joint ventures and $3.6 \%$ has not classified themselves to these categories. Contrary to this, in $2013,58.1 \%$ of the companies were Hungarian- owned, $37.2 \%$ foreigners, $3.5 \%$ joint ventures and $1.2 \%$ signed 'other' category.

The organisations operated in these different sectors are shown in the Table 1.

Table 1: Organisations on the basis of sector activities (\%)

\begin{tabular}{|l|c|c|}
\hline \multirow{2}{*}{\multicolumn{1}{|c|}{ Sector }} & \multicolumn{2}{c|}{$\%$} \\
\cline { 2 - 3 } & $\mathbf{2 0 1 3}$ & $\mathbf{2 0 1 5}$ \\
\hline Health Care & 2.3 & 4.8 \\
\hline Energy & 11.5 & 2.4 \\
\hline FMCG & 1.1 & 1.2 \\
\hline Business services & 4.6 & 7.2 \\
\hline Industry & 12.6 & 10.8 \\
\hline IT & 6.9 & 6.0 \\
\hline Commerce & 1.1 & 14.5 \\
\hline Public administration & 9.2 & 9.6 \\
\hline Education & 4.6 & 7.2 \\
\hline Financial sector & 21.8 & 9.6 \\
\hline Telecommunication & 4.6 & 3.6 \\
\hline Logistic & 0 & 2.4 \\
\hline Other & 19.5 & 20.5 \\
\hline Total & $\mathbf{1 0 0 . 0}$ & $\mathbf{1 0 0 . 0}$ \\
\hline
\end{tabular}

Source: Authors' analysis

Table 1 shows that there were several companies from various sectors. As far as the rate of the participants are concerned, we can see that the energy, finance and industry sector gave the highest rate from participants in 2013. In 2015 the sectors of commerce, industry and public services accounted for the biggest part of the sample. The figures in the other category was high in both years. In the first research $58.8 \%$ of the firms were private companies, $36.5 \%$ governmental organizations. In 2015, $70.7 \%$ were private companies, and $25.6 \%$ governmental bodies, $3.7 \%$ was other category.

As we have seen, the number of the employees in 2013, one third of the sample, has more than thousand employees, but in 2015 it became less, only one fifth of it had more than thousands employees. This number is also related to the existence of HR department, as in 2013 when $75.9 \%$ of the researched firms had HR department, and in 2015 this rate was $70.7 \%$.

The second part of the research focused on the effect of the global crisis. We had the same questions in the two different years (What elements occur recovering from the crisis, the growth impact for your company in the field of employment?), but there were different aspects in the evaluation with 5-grade Likert scale, so this would be superficial for the two-year comparison.

In 2013, the following items were evaluated by the firms, where number 1 meant not typical, 5 meant highly typical. The chart below summarizes the average and the dispersion of the given values.

It can be seen from the Table 2, that the reducing of the number of employees and dismantling the contract workers as tools were typical, so the employers focused on the reduction numbers of the employees and less on the wages.

In 2015, employers had to answer whether the concrete phenomenon was typical in a 5 grade Likert scale within their company. The Table 3 shows the answers from 2015.

Table 2: Effects of crisis in 2013.

\begin{tabular}{|c|c|c|c|c|}
\hline \multirow[b]{2}{*}{ Definition } & \multicolumn{2}{|c|}{$\mathbf{N}$} & \multirow[b]{2}{*}{ Average } & \multirow[b]{2}{*}{ Dispersion } \\
\hline & Valid & $\begin{array}{c}\text { Missing } \\
\text { data }\end{array}$ & & \\
\hline Reduction of the number of employees & 85 & 2 & 2.35 & 1.251 \\
\hline Dismantling the contract workers & 83 & 4 & 2.10 & 1.294 \\
\hline Reduction of the number of shifts & 83 & 4 & 1.43 & .784 \\
\hline Reduction of the number of working days & 82 & 5 & 1.30 & .765 \\
\hline Reduction of wages & 84 & 3 & 1.79 & 1.120 \\
\hline
\end{tabular}

Source: Authors analysis 
I. Csapó Flexible employment forms in different companies

et al. located in Budapest

Table 3: Effects of crisis in 2015.

\begin{tabular}{|l|c|c|c|c|}
\hline \multirow{2}{*}{\multicolumn{1}{|c|}{ Definition }} & \multicolumn{2}{|c|}{ N } & \multirow{2}{*}{ Average } & Dispersion \\
\cline { 2 - 4 } & Valid & $\begin{array}{c}\text { Missing } \\
\text { data }\end{array}$ & & \\
\hline Increasing number of employees & 82 & 1 & 2.28 & 1.250 \\
\hline Increasing number of contract workers & 82 & 1 & 1.96 & 1.116 \\
\hline Increasing number of shifts & 82 & 1 & 1.30 & .765 \\
\hline Increasing number of weekly working days & 81 & 2 & 1.19 & .615 \\
\hline Increasing of wages & 82 & 1 & 2.27 & .994 \\
\hline There are no changes & 81 & 2 & 2.38 & 1.374 \\
\hline Reducing number of employees & 82 & 1 & 1.32 & .646 \\
\hline Other & 22 & 61 & 2.05 & 1.527 \\
\hline
\end{tabular}

Source: Authors analysis

The results confirmed that the companies did not plan essential changes, while it was planned to increase the number of employees and also to increase wages. Thus, the firms were a bit more optimistic in 2015, compared to 2013, in the special field of the employment growth.

The following questions focused on the different actions that the companies planned to use to ensure the recovery from crisis. The variables were the same in the two researches, thus it was effective to compare the dates. The summarized values can be seen in the Table 4.

Based on the responses it can be stated that different firms increased their engagement related to stop reducing the number of employees and to develop their technical and organizational efficiency. Contrary to this, the willingness for outsourcing, using atypical employment tools and the employment of cheap workforce were reduced. This may mean that an increasing need is appearing for the changes of internal employment structure and policy. The experts examined which variables showed significant difference for the two years. As the variables were not normally distributed, nonparametric analysis was conducted by the authors - Table 5 .

The nonparametric test has shown that high differences can be seen regarding the outsourcing and the employment of cheaper employees. Naturally, we have to take into consideration that the two samples were different related the two years, but as the results showed, firms are more optimistic regarding developing their employment policy and in increasing the number of their employees.

At the end, the authors wanted to have information about the samples attitude's regarding the atypical employment. The respondents had to answer different questions supported by a Likert scale. The Table 6. summarizes the results for the two years.

Table 4: What provisions were planned to ensure the recovery from crisis in 2013, 2015.

\begin{tabular}{|c|c|c|c|c|c|c|c|c|}
\hline \multirow{3}{*}{ Definition } & \multicolumn{4}{|c|}{2013} & \multicolumn{4}{|c|}{2015} \\
\hline & \multicolumn{2}{|r|}{$\mathbf{N}$} & \multirow[b]{2}{*}{ Average } & \multirow[b]{2}{*}{ Dispersion } & \multicolumn{2}{|r|}{$\mathbf{N}$} & \multirow[b]{2}{*}{ Average } & \multirow[b]{2}{*}{ Dispersion } \\
\hline & Valid & $\begin{array}{c}\text { Missing } \\
\text { data }\end{array}$ & & & Valid & $\begin{array}{c}\text { Missing } \\
\text { data }\end{array}$ & & \\
\hline $\begin{array}{l}\text { Increasing the atypical } \\
\text { employment }\end{array}$ & 80 & 7 & 2.35 & 1.233 & 79 & 4 & 2.10 & 1.069 \\
\hline Cheaper working force & 80 & 7 & 2.18 & 1.220 & 79 & 4 & 1.65 & .948 \\
\hline Outsourcing & 80 & 7 & 2.28 & 1.331 & 77 & 6 & 1.79 & .991 \\
\hline Stop freezing wages & 78 & 9 & 1.96 & 1.294 & 76 & 7 & 2.00 & 1.286 \\
\hline $\begin{array}{l}\text { Stop reducing the number } \\
\text { of employees }\end{array}$ & 80 & 7 & 2.16 & 1.267 & 76 & 7 & 2.29 & 1.468 \\
\hline Technological development & 79 & 8 & 2.33 & 1.366 & 78 & 5 & 2.68 & 1.233 \\
\hline $\begin{array}{l}\text { Product development, } \\
\text { production of new products }\end{array}$ & 79 & 8 & 3.04 & 1.363 & 78 & 5 & 2.86 & 1.430 \\
\hline $\begin{array}{l}\text { Increasing Organizational } \\
\text { Efficiency }\end{array}$ & 82 & 5 & 3.63 & 1.149 & 80 & 3 & 3.69 & 1.165 \\
\hline
\end{tabular}

Source: Authors analysis 
I. Csapó Flexible employment forms in different companies

et al. located in Budapest

Table 5: Nonparametric test $p=0,05$

\begin{tabular}{|l|c|c|c|c|}
\hline \multicolumn{1}{|c|}{ Definition } & $\begin{array}{c}\text { Mann- } \\
\text { Whitney U U }\end{array}$ & $\begin{array}{c}\text { Wilcoxon } \\
\text { W }\end{array}$ & $\mathbf{Z}$ & $\begin{array}{c}\text { Asymp. } \\
\text { Sig. (2-tailed) }\end{array}$ \\
\hline Increasing the atypical employment & 2831.000 & 5991.000 & -1.178 & .239 \\
\hline Cheaper working force & 2389.000 & 5549.000 & -2.875 & .004 \\
\hline Outsourcing & 2485.500 & 5488.500 & -2.226 & .026 \\
\hline Stop freezing wages & 2907.000 & 5988.000 & -.225 & .822 \\
\hline Stop reducing the number of employees & 3014.000 & 6254.000 & -.097 & .923 \\
\hline Technological development & 2554.500 & 5714.500 & -1.903 & .057 \\
\hline Product development, production of new products & 2864.500 & 5945.500 & -.779 & .436 \\
\hline Increasing Organizational Efficiency & 3176.500 & 6579.500 & -.360 & .718 \\
\hline
\end{tabular}

Source: Authors analysis

Table 6: Attitudes regarding the atypical employment

\begin{tabular}{|c|c|c|c|c|c|c|c|c|}
\hline \multirow{3}{*}{ Definition } & \multicolumn{4}{|c|}{2013} & \multicolumn{4}{|c|}{2015} \\
\hline & \multicolumn{2}{|r|}{$\mathbf{N}$} & \multirow[b]{2}{*}{ Average } & \multirow[b]{2}{*}{ Dispersion } & \multicolumn{2}{|r|}{$\mathbf{N}$} & \multirow[b]{2}{*}{ Average } & \multirow[b]{2}{*}{ Dispersion } \\
\hline & Valid & $\begin{array}{c}\text { Missing } \\
\text { data }\end{array}$ & & & Valid & $\begin{array}{c}\text { Missing } \\
\text { data }\end{array}$ & & \\
\hline $\begin{array}{l}\text { I do not know the atypical } \\
\text { employment forms }\end{array}$ & 84 & 3 & 1.88 & 1.176 & 81 & 2 & 1.86 & 1.191 \\
\hline $\begin{array}{l}\text { We used, but we had no } \\
\text { good experiences }\end{array}$ & 85 & 2 & 1.88 & .918 & 78 & 5 & 2.08 & .908 \\
\hline $\begin{array}{l}\text { I know, but we do not want } \\
\text { to change the current } \\
\text { employment system }\end{array}$ & 85 & 2 & 2.99 & 1.384 & 80 & 3 & 3.04 & 1.364 \\
\hline $\begin{array}{l}\text { I know, but we have no jobs } \\
\text { where we can use the } \\
\text { atypical forms }\end{array}$ & 85 & 2 & 2.22 & 1.294 & 80 & 3 & 2.13 & 1.277 \\
\hline $\begin{array}{l}\text { Our leaders prefer } \\
\text { traditional employment } \\
\text { forms to atypical } \\
\text { employment tools. }\end{array}$ & 85 & 2 & 2.81 & 1.384 & 81 & 2 & 3.27 & $1, .423$ \\
\hline $\begin{array}{l}\text { We employ disadvantaged } \\
\text { workers }\end{array}$ & 82 & 5 & 3.12 & 1.201 & 79 & 4 & 3.20 & 1.102 \\
\hline $\begin{array}{l}\text { There is an organization } \\
\text { which can support atypical } \\
\text { employment }\end{array}$ & 80 & 7 & 3.10 & 1.165 & 78 & 5 & 3.22 & 1.180 \\
\hline $\begin{array}{l}\text { Workers back from long } \\
\text { term unemployment should } \\
\text { be employed with the same } \\
\text { conditions }\end{array}$ & 83 & 4 & 3.75 & 1.146 & 80 & 3 & 3.95 & 1.054 \\
\hline $\begin{array}{l}\text { I have activities which do } \\
\text { not need to stay in the } \\
\text { workplace }\end{array}$ & 82 & 5 & 3.54 & 1.278 & 78 & 5 & 3.73 & 1.296 \\
\hline $\begin{array}{l}\text { Happy to work with } \\
\text { temporary employment } \\
\text { companies. }\end{array}$ & 85 & 2 & 2.78 & 1.285 & 78 & 5 & 2.76 & 1.311 \\
\hline $\begin{array}{l}\text { I see that my employees } \\
\text { would like to work within } \\
\text { the framework of atypical } \\
\text { forms of employment. }\end{array}$ & 83 & 4 & 3.04 & 1.194 & 80 & 3 & 3.08 & 1.178 \\
\hline
\end{tabular}

Source: Authors analysis

Based on the study of two years the results showed that the leaders accepted atypical forms less in comparison with other conventional working models. They did not have better experience atypical forms than in 2013. The average respondents said that in 2015 they did not have good experience in contrast to atypical forms in 2013. In spite of the fact that companies seemed to be more reserved to atypical forms, they claimed they had several activities, which did not require 
staying at the work place. Therefore, different type of atypical forms could provide right solutions, such as tele- work. Furthermore, also the employees were open to atypical forms to lesser degree.
The authors also examined if there were the cases of significant differences during the two-year's period. Since the variables were not normally distributed non-parametric method was applied in the difference study - Table 7.

Table 7: Nonparametric test $p=0,05$

\begin{tabular}{|l|c|c|c|c|}
\hline \multicolumn{1}{|c|}{ Definition } & $\begin{array}{c}\text { Mann- } \\
\text { Whitney U }\end{array}$ & $\begin{array}{c}\text { Wilcoxon } \\
\text { W }\end{array}$ & Z & $\begin{array}{c}\text { Asymp. } \\
\text { Sig. (2-tailed) }\end{array}$ \\
\hline I do not know the atypical employment forms & 333.500 & 6654.500 & -.246 & .806 \\
\hline We used, but we had no good experiences & 2905.500 & 6560.500 & -1.436 & .151 \\
\hline $\begin{array}{l}\text { I know, but we do not want to change the } \\
\text { current employment system. }\end{array}$ & 3334.000 & 6989.000 & -.220 & .825 \\
\hline $\begin{array}{l}\text { I know, but we have no jobs where we can use } \\
\text { the atypical forms }\end{array}$ & 3236.500 & 6476.500 & -.560 & .576 \\
\hline $\begin{array}{l}\text { Our leaders prefer traditional employment } \\
\text { forms than atypical employment tools }\end{array}$ & 2795.500 & 6450.500 & -2.136 & .033 \\
\hline $\begin{array}{l}\text { We employ disadvantaged workers } \\
\text { There is an organization which can support } \\
\text { atypical employment }\end{array}$ & 3151.000 & 6554.000 & -.309 & .758 \\
\hline $\begin{array}{l}\text { Workers back from long term unemployment } \\
\text { should be employed with the same conditions }\end{array}$ & 2973.000 & 6213.000 & -.534 & .593 \\
\hline $\begin{array}{l}\text { I have activities which do not need to stay } \\
\text { in the workplace }\end{array}$ & 2872.000 & 6275.000 & -1.162 & .245 \\
\hline $\begin{array}{l}\text { Happy to work with temporary employment } \\
\text { companies. }\end{array}$ & 3291.000 & 6372.000 & -.082 & .935 \\
\hline $\begin{array}{l}\text { I see that my employees would like to work within } \\
\text { the framework of atypical forms of employment. }\end{array}$ & 3189.500 & 6675.500 & -.446 & .656 \\
\hline
\end{tabular}

Source: Authors analysis

Based on the non-parametric analyses and the twoyear-study, the results showed that leaders were less inclined towards atypical forms of work in relation to conventional working models and they typically have declared a higher average.

\section{SUMMARY}

The study was made as a comparative research from 2013 and 2015, examining the institutional reactions on the crisis regarding different HR tools and the possibilities of atypical employment. All the firms operated in the capital of Budapest, therefore the results of the research should be considered as limited sample. The studies have shown that companies were more optimistic in 2015 , both have seen their potential investment in the field of technical development as well as in the field of employment, but they preferred the traditional tools and methods regarding the employment.

\section{REFERENCIES}

Bokor, A., Szőts-Kováts, K., Csillag, S., Bécsi, K., \& Szilas, R. (2007). Emberierőforrás-menedzsment
(Human resource management). In Hungary Budapest, Hungary: AULA.

Broughton, A., Biletta, I., \& Kullander, M. (2010). Flexible forms of work: 'very atypical' contractual arrangements. Retrieved 10.10.2016, from Eurofound https://www.eurofound.europa.eu/observatories/eur work/comparative-information/flexible-forms-ofwork-very-atypical-contractual-arrangements

Elbaum, M. (1988). Petits boulots, stages, emplois précaires: quelle flexibilité pour quelle insertion. Droit social, 4, 311-316.

Hárs, Á. (2013). Atipikus foglalkoztatási formák Magyarországon a kilencvenes és a kétezres években (Atypical forms of employment in Hungary in the nineties and this decade). In: Hungary Közgazdasági Szemle, LX, 224-250.

Jackson, P. J., \& van der Wielen, J. M. (Eds.). (1998). Teleworking: International Perspectives: from Telecommuting to the Virtual Organisation: Routledge.

Laky, T. (2001). Az atipikus foglalkozások (Atypical jobs).In Hungary Budapest: Struktúra Munkaügyi Kiadó.

Lewis, C. P. (2004). How the East was Won: The Impact of Multinational Companies on the Transformation of Eastern Europe and the Former Soviet Union: Palgrave Macmillan. 
Lipták, K. (2011). Is atypical typical? - atypical employment in Central Eastern European countries. Employment and economy in Central and Eastern Europe, 1/2011.

Ogura, K. (2005). International comparison of atypical employment: Differing concepts and realities in industrialized countries. Japan Labor Review, 2(2), 5-29.

Poór, J., Farkas, F., \& Engle, A. D. (Eds.). (2012). Human Resource Management Issues and Challenges in Foreign Owned Companies: Central and Eastern Europe. Komárno: UNIVERZITA J. SELYEHO - Ekonomická fakulta.

Strážovská, H., Strážovská, L., Szabó, I., Szabó, K., \& Vinogradov, S. (2014). Foglalkoztatás - atipikus foglalkoztatás a magyar - szlovák határmentén Komárno - Komárom és Párkány - Esztergom térségében (Employment - atypical employment in the Hungarian-Slovak border area - Komárno Komárom and Párkány - Esztergom region). In I. Antalík, M. Dús, T. Gábrielné, Gy., M. Gősi, Z. Horbulák, T. Juhász, C. Kollár, I. É. Kovács, I.
Madarász, N. Mihály \& J. Poór (Eds.), Final resource report in typical and atypical employment in Hungarian and Slovak cross-border area in focus Komarno-Komarom and Parkany-Esztergom regions 2014. Gödöllő - Komárom/Komárno.

Schleicher, N. (2007). Kvalitatív kutatási módszerek a társadalomtudományokban (Methods of quantitative research in the social sciences). Budapest: BKF.

Stavrou, E. T. (2005). Flexible work bundles and organizational competitiveness: a cross-national study of the European work context. Journal of Organizational Behavior, 26(8), 923-947. doi: 10.1002/job.356

Szabó, K., \& Négyesi, Á. (2004). Atypical forms in knowledge management (The causes of atypical work in the knowledge economy). In Hungary Közgazdasági Szemle, LI, 46-65.

Tung, R. L., \& Havlovic, S. J. (1996). Human resource management in transitional economies: the case of Poland and the Czech Republic. The International Journal of Human Resource Management, 7(1), 119. doi: 10.1080/09585199600000115

\title{
OBLICI FLEKSIBILNOG ZAPOŠLJAVANJA U RAZLIČITIM KOMPANIJAMA IZ BUDIMPEŠTE
}

\begin{abstract}
Atipično zapošljavanje kao fleksibilan oblik zapošljavanja danas privlači sve veću pažnju istraživača koji se bave istraživanjem radnih odnosa. Kao rezultat ekonomske krize, fleksibilno zapošljavanje se pojavilo kao alternativno rešenje jer je umanjilo negativne efekte krize. Autori ovog rada su istraživali kako su različite kompanije sa sedištem u Budimpešti reagovale na ekonomsku krizu. Da li su bile više naklonjene fleksibilnom zapošljavanju kao mogućem I efikasnom načinu zapošljavanja? U toku 2013. I 2015. godine, istrživači su sproveli anketu na osnovu koje su testirali rezultate ove studije, a neki od rezultata kvantitativnog istraživanja su prikazani u Budimpešti. Na osnovu rezultata analize iz 2015.godine vidi se da su preduzeća pokazala veći stepen optimizma, što predstavlja manifestaciju volje da se proširi zaposlenost, kako je I prikazano. Cilj autora ovog istraživanja bio je da pruži relevantne odgovore koji se odnose na nove metode fleksibilnog zapošljavanja.
\end{abstract}

Ključne reči: Atipičan rad, Fleksibilan oblik zapošljavanja, Ekonomska kriza, Alternativno rešenje. 